\title{
CODA $\boldsymbol{H}$ VULNERABLE POPULATIONS
}

\section{Patient sketches}

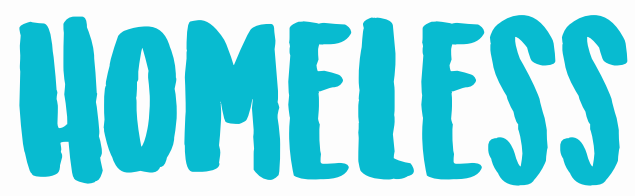

Alan Blum MD

Cite as: CMAJ 2019 June 3;191:E624. doi: 10.1503/cmaj.190403
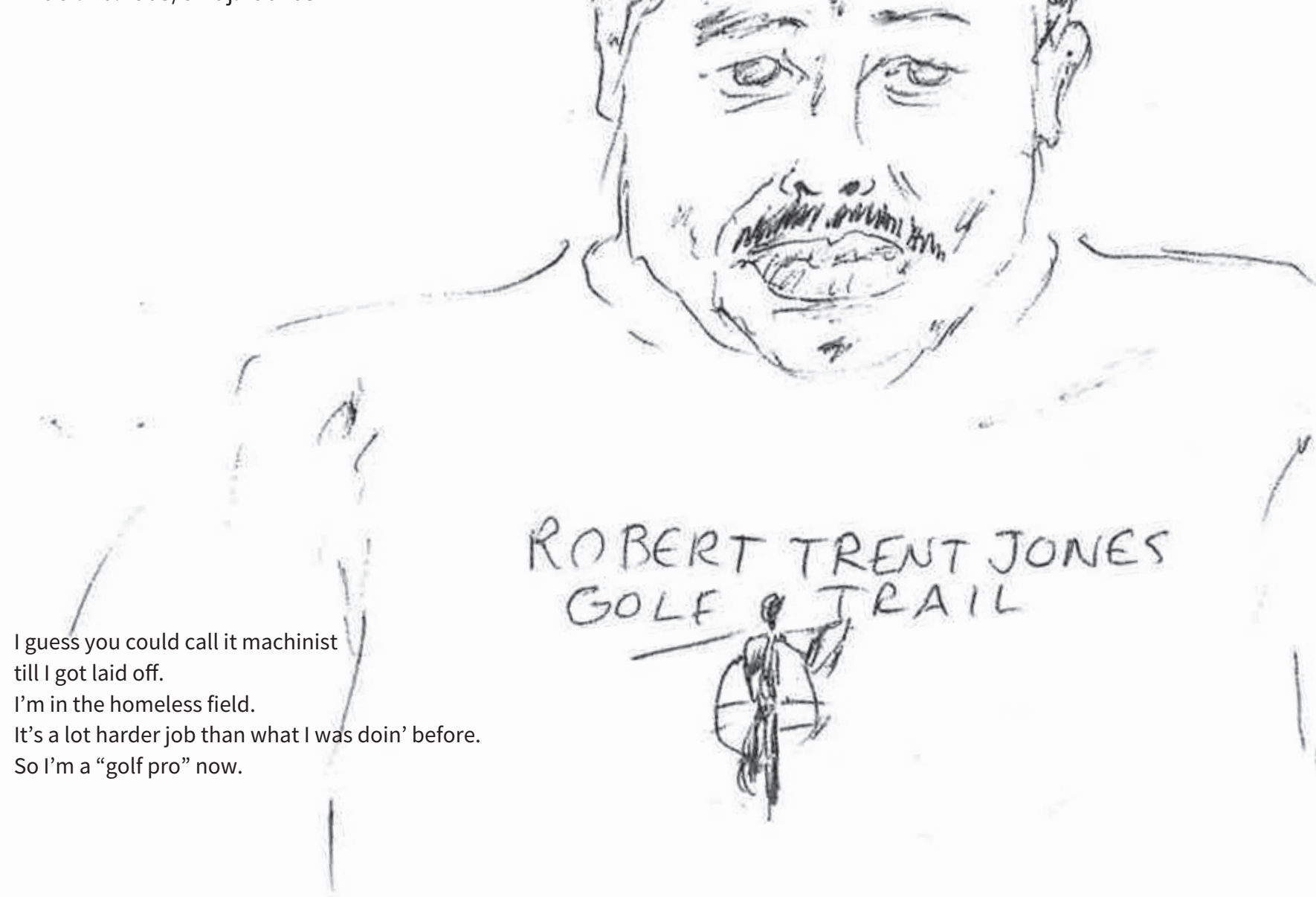

See other sketches and notes by this author at cmaj.ca.

This sketch and note date back more than three decades.

Correspondence to: ablum@ua.edu 